\title{
THE EFFECT OF MINIMAL MARKING FEEDBACK FOR TEACHING PARAGRAPH WRITING
}

\author{
Surya Darmawan ${ }^{1}$, Irma Savitri Sadikin ${ }^{2}$, Yanuarti Apsari ${ }^{3}$ \\ ${ }^{1}$ IKIP Siliwangi \\ ${ }^{2}$ Universitas Esa Unggul \\ ${ }^{3}$ IKIP Siliwangi \\ ${ }^{1}$ suryadarmawan07@gmail.com, ${ }^{2}$ irma.savitri@esa unggul.ac.id, ${ }^{3}$ yanuar.apsari1@gmail.com
}

\begin{abstract}
Giving feedback to the students can help them to be better in their writing skill. Therefore, the teacher should give an alternative way in giving feedback to encourage students to master writing skill. There are a lot of kinds of feedback, one of them is using minimal marking feedback. The main objective of this study is to investigate the effectiveness of minimal marking feedback towards students' ability in writing descriptive text. It used quantitative method with quasi-experimental design to get the result. It was conducted in one of Junior High Schools in West Java with two classes as the samples. The process started by dividing the students into two categories, namely experimental group and control group. The group which was given treatment by minimal marking feedback in writing descriptive text was experimental one. The treatment was given in five meetings for experimental group. Meanwhile, the control group did not have that treatment for writing the descriptive text. After having the treatment for five meetings, it can be seen that there was significant improvement for those who are in experimental group. This was proven by the data calculated by IBM SPSS Statistics version 23 . The result of the calculation by using T-Test showed that Sig.(2-tailed) is 0.000 which was lower than 0.05 meaning that the null hypothesis was rejected. Therefore, the treatment which was given to experiment group was significantly improve students' ability in writing descriptive text.
\end{abstract}

Keywords: Writing, Descriptive text, Minimal Marking Feedback

\section{INTRODUCTION}

English as a global language in all over the world seems to be a priority for people to learn. It is because as social creatures, people absolutely need to communicate in their everyday life in order to socialize or to express their thought, feeling, understanding, opinion, critic, and everything that they want to share to others. In Indonesia, English is a part of subject that should learn by the students. The language have four language skills to be mastered are listening, speaking, reading and writing. By mastering four language skills, students are expected to be able to communicate fluently in English both spoken and written.

Many students had difficulties in mastering writing skill. Sometimes they may understand what the teacher means but they are not able to deliver it well in the written form. Besides, other difficulties that are faced by the students in mastering writing skill are, firstly the process of writing requires an entirely different set of competencies and is fundamentally different from speaking (Brown \& Lee, 2015: 335). Secondly, written products are often the result of thinking, drafting, and revising procedures that require specialized skills, skills that not every speaker develops naturally (Brown \& Lee, 2015: 335). Thirdly, many students either think or say that they cannot, or do not want to write because they lack of confident, think it is boring or believe they have 'nothing to say' (Harmer, 2007: 113). Therefore, regarding to those difficulties faced 
by the students, this research will try to give an alternative way in giving feedback to encourage students to master writing skill. Since there are a lot of possible ways in encouraging them to master that skill, the researcher will focus on the use of minimal marking feedback to the students' writing, especially in the students' writing descriptive texts. Moreover, the researcher comes up with a question “does minimal marking feedback improve students' ability in writing descriptive text?"

\section{Writing}

Writing is a complex activity since it requires students' comprehensive abilities such as mastering grammar, vocabulary, and punctuation (Brown \& Lee, 2015: 337). Moreover, to write well, the students are expected to be able to present their ideas in the written form as writing is a means of communication. Brown \& Lee (2015: 334) says that writing is similar to swimming which means that somebody is able to swim if someone else teaches him how to do so and so is writing. Briefly, if a student is willing to be able to express his ideas in the written form, he/she needs someone else to guide and teaches him how to do so well and appropriately. A good writing skill will not appear at once. Oshima \& Hogue (2008: 33) claim that writing skill needs process which has four stages which are summarized as follows:

1. Pre-writing: it is the first stage in the writing process. There are two steps namely choosing and narrowing a topic and brainstorming.

2. Planning (Outlining): it organize the ideas the learners generated by brainstorming into an outline. There are three steps on planning that is: making sub lists, writing the topic sentence, and outlining.

3. Writing and Revising Draft: in this stage, a writer does three steps: writing the first rough draft, revising content and organization, and proofreading the second draft.

4. Writing the Final Copy to Hand in: As the final activity in a writing process, a writer has to rework the written drafts and polish them for the presentation or publication.

\section{Feedback}

Feedback is information that is provided to students about whether or not their production and interpretation of language is appropriate (Cameroon, 2001: 237). This may be in the form of direct correction, or it may take more indirect forms (Saville \& Troike, 2006: 188). In other words, feedback is what teachers tell the students about how well they have done in terms of the language they have used or task they have performed (Harmer, 2007: 274). Moreover, to succeed any kinds of feedback, it would be beneficial for the students to have feedback continually and consistantly from the teacher. If the students make several mistakes, and the teacher helps to correct them by giving some feedback, it can challenge them to realize their mistakes and the students really learn from them (Thompson, 2009: 374). It is because, the practice of giving feedback is the ongoing systematic review of knowledge until the students master particular material (Gronlund, 1990: 203). Thus, they begin to see the connection between their efforts and what they have learned and also what the expert, in this case teacher, view they work. Besides, by the pactice of it, the students will have more awarness to go back and check their work before giving it to the teacher because they know what is wrong (Wiersma \& Jurs, 1990: 9).

It is identified that feedback has several purposes in the practice of teaching and learning process as conveyed by Muth'im \& Latief (2014: 246), Lewis (2002: 124). They further declare that the purposes are: 1) giving information for teachers and learners; 2) providing students with advice about learning; 3) providing students with language input; 4) promoting the learners toward their autonomy. Types of feedback have their own characteristics. This is in accordance 
with Grabe \& Kaplan (2014), Ferris (2011) and Hyland (2003) explaining those forms in this following table.

Table 1. Forms of Feedback

\begin{tabular}{|c|c|c|}
\hline Types & Forms & Characteristics \\
\hline \multirow[b]{3}{*}{$\begin{array}{l}\text { Teacher Written } \\
\text { Feedback }\end{array}$} & Commentary & $\begin{array}{l}\text { - The most common feedback } \\
\text { - Handwritten feedback on students' } \\
\text { paper }\end{array}$ \\
\hline & Rubrics & $\begin{array}{l}\text { A variation of commentary } \\
\text { - The use of cover sheet with criteria }\end{array}$ \\
\hline & Minimal Marking & $\begin{array}{l}\text { - A type of in-text, form based feedback } \\
\text { Indication of location and perhaps type } \\
\text { of errors rather than direct correction } \\
\text { - More effective in stimulating a student } \\
\text { response and in developing self- } \\
\text { editing strategies }\end{array}$ \\
\hline
\end{tabular}

This present study implements minimal marking feedback which is a kind of indirect feedback and it can be used as a clue for students that there is something that they need to fix (Purnawarman, 2013:30). The minimal marking process helps the learners recognize, diagnose, and correct their own typical error. This type of feedback is more effective and time-efficient method than the traditional teacher "red-markings" to encourage and help the learners improve sentence-level errors (McNeilly, 2014). She found that minimal marking feedback could reduce the number of grammatical and errors in students' writing. Indirect feedback, in which teacher gives comments on students' writing, can be beneficial to guide learning and help the learners in solving problems (Lalande, 1982 in Srichanyachon, 2012) On the other hand, the danger of giving indirect feedback is about possible confusion faced by the students (Srichanyachon, 2012: 16). It is because, indirect feedback only allows the teacher to give several clues related to the writing. Moreover, there is possibility of misunderstanding between what the teacher is trying to say and the interpretation of the students. However, the problems can be minimalized by giving them explanation about the mistakes they have in their work. The researcher continued with short review explanation about descriptive text and common mistakes faced by the students during the learning process.

\section{METHOD}

In carrying out the study, the researcher used quantitative method. Aliaga and Gunderson in Andie, Muijis, \& McAteer (2011: 121) who state "Quantitative research is explaining phenomena by collecting numerical data that are analysis using mathematically based methods in particular statistics." This present study used quasi-experimental design with two groups. The first group called as experiment class with pretest-posttest design that involves three steps. The first step is the students will be given pretest (Q1), the second step is the application of the treatment $(\mathrm{X})$ and the final step is the posttest $(\mathrm{Q} 2)$. In the other hand second group called as control class involves two steps. The first step is the students will be given pretest (Q3) and the second step is posttest (Q4). There is no treatment for control class.

\section{Table 2}

\section{Quasi Experimental Design}




\begin{tabular}{llll}
\hline Class & Pre-test & Treatment & Post-test \\
\hline Experiment & Q1 & T & Q2 \\
\hline Control & Q3 & O & Q4 \\
\hline
\end{tabular}

The population of this study was eight grade students of one of Junior High Schools in West Java in academic year 2018-2019. There were two classes as the sample of the study. The researchers gave a pre-test at the beginning of meeting, and then they taught writing descriptive text using minimal marking feedback for 10 meetings. In the last meeting, she gave a post-test.

\section{RESULTS AND DISCUSSION}

\section{Results}

As describe earlier, this research tried to answer the following question: Does minimal marking feedback improve students' ability in writing descriptive text?. In the relation to the object above, the researcher collected the data from students pre-test and post-test.

\section{Test Results in Experiment Class}

The data as result of the pre-test in experimental class can be read on table 4.1. Based on the table presented, it can be seen that the highest score in the pretest is 56.25 and the lowest score is 25.00. Meanwhile, the average score that the students got is 45.62. The students getting the highest score were 10 students. They understood about general descriptive material. It described with the score that they got in organization, content and vocabulary. On the other hand, the students getting the lowest score were 6. They did not understand well about descriptive text, especially several such as content, organization, vocabulary and grammar.

Table 3

Pre-test and Post-test Score of Experimental Class Pre-test Score of Experimental Class Post-test Score of Experimental Class

\begin{tabular}{|c|c|c|c|c|c|c|c|c|c|c|c|c|}
\hline Name & 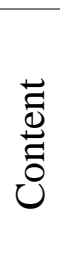 & 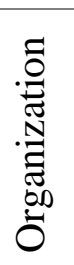 & 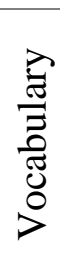 & 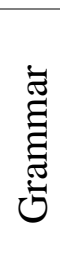 & & $\begin{array}{l}0 \\
\check{0} \\
\tilde{S}\end{array}$ & 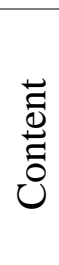 & 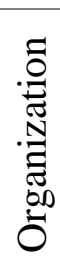 & 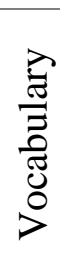 & 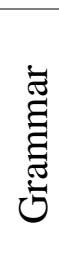 & 吾 & $\begin{array}{l}0 \\
: 0 \\
\mathscr{U}\end{array}$ \\
\hline S1 & 2 & 3 & 2 & 2 & 9 & 56.25 & 2 & 3 & 2 & 2 & 9 & 56.25 \\
\hline S2 & 2 & 2 & 3 & 2 & 9 & 56.25 & 2 & 2 & 3 & 2 & 9 & 56.25 \\
\hline S3 & 2 & 2 & 2 & 2 & 8 & 50.00 & 2 & 2 & 2 & 2 & 8 & 50.00 \\
\hline S4 & 2 & 3 & 2 & 2 & 9 & 56.25 & 2 & 3 & 2 & 2 & 9 & 56.25 \\
\hline S5 & 2 & 2 & 2 & 2 & 8 & 50.00 & 2 & 2 & 2 & 2 & 8 & 50.00 \\
\hline S6 & 3 & 2 & 2 & 2 & 9 & 56.25 & 3 & 2 & 2 & 2 & 9 & 56.25 \\
\hline S7 & 2 & 2 & 2 & 2 & 8 & 50.00 & 2 & 2 & 2 & 2 & 8 & 50.00 \\
\hline S8 & 2 & 2 & 2 & 2 & 8 & 50.00 & 2 & 2 & 2 & 2 & 8 & 50.00 \\
\hline S9 & 1 & 1 & 1 & 1 & 4 & 25.00 & 1 & 1 & 1 & 1 & 4 & 25.00 \\
\hline S10 & 1 & 1 & 1 & 1 & 4 & 25.00 & 1 & 1 & 1 & 1 & 4 & 25.00 \\
\hline
\end{tabular}




\begin{tabular}{lllllllllllll}
\hline S11 & 2 & 2 & 3 & 2 & 9 & 56.25 & 2 & 2 & 3 & 2 & 9 & 56.25 \\
\hline $\mathbf{S 1 2}$ & 2 & 2 & 2 & 2 & 8 & 50.00 & 2 & 2 & 2 & 2 & 8 & 50.00 \\
\hline $\mathbf{S 1 3}$ & 1 & 1 & 1 & 1 & 4 & 25.00 & 1 & 1 & 1 & 1 & 4 & 25.00 \\
\hline $\mathbf{S 1 4}$ & 2 & 2 & 2 & 2 & 8 & 50.00 & 2 & 2 & 2 & 2 & 8 & 50.00 \\
\hline $\mathbf{S 1 5}$ & 2 & 2 & 2 & 2 & 8 & 50.00 & 2 & 2 & 2 & 2 & 8 & 50.00 \\
\hline $\mathbf{S 1 6}$ & 1 & 1 & 1 & 1 & 4 & 25.00 & 1 & 1 & 1 & 1 & 4 & 25.00 \\
\hline $\mathbf{S 1 7}$ & 2 & 3 & 2 & 2 & 9 & 56.25 & 2 & 3 & 2 & 2 & 9 & 56.25 \\
\hline $\mathbf{S 1 8}$ & 1 & 1 & 1 & 1 & 4 & 25.00 & 1 & 1 & 1 & 1 & 4 & 25.00 \\
\hline $\mathbf{S 1 9}$ & 3 & 2 & 2 & 2 & 9 & 56.25 & 3 & 2 & 2 & 2 & 9 & 56.25 \\
\hline $\mathbf{S 2 0}$ & 1 & 1 & 1 & 1 & 4 & 25.00 & 1 & 1 & 1 & 1 & 4 & 25.00 \\
\hline $\mathbf{S 2 1}$ & 2 & 3 & 2 & 2 & 9 & 56.25 & 2 & 3 & 2 & 2 & 9 & 56.25 \\
\hline $\mathbf{S 2 2}$ & 2 & 2 & 2 & 2 & 8 & 50.00 & 2 & 2 & 2 & 2 & 8 & 50.00 \\
\hline $\mathbf{S 2 3}$ & 2 & 2 & 3 & 2 & 9 & 56.25 & 2 & 2 & 3 & 2 & 9 & 56.25 \\
\hline $\mathbf{S 2 3}$ & 2 & 2 & 3 & 2 & 9 & 56.25 & 2 & 2 & 3 & 2 & 9 & 56.25 \\
\hline $\mathbf{S 2 5}$ & 2 & 2 & 1 & 2 & 7 & 43.75 & 2 & 2 & 1 & 2 & 7 & 43.75 \\
\hline $\mathbf{S 2 6}$ & 2 & 2 & 2 & 2 & 8 & 50.00 & 2 & 2 & 2 & 2 & 8 & 50.00 \\
\hline $\mathbf{S 2 7}$ & 2 & 2 & 2 & 2 & 8 & 50.00 & 2 & 2 & 2 & 2 & 8 & 50.00 \\
\hline S28 & 1 & 1 & 1 & 2 & 5 & 31.25 & 1 & 1 & 1 & 2 & 5 & 31.25 \\
\hline S29 & 1 & 1 & 1 & 2 & 5 & 31.25 & 1 & 1 & 1 & 2 & 5 & 31.25 \\
\hline S30 & 2 & 2 & 2 & 2 & 8 & 50.00 & 2 & 2 & 2 & 2 & 8 & 50.00 \\
\hline
\end{tabular}

In contrast, the rest of the students could understand well about aspects organization and vocabulary. But, they had some difficulties in creating their writing based on good content and grammar. Mostly, they were still confused with grammar used in descriptive text. The students getting the highest score were 11 students. They understood about general descriptive material. It described with the score that they got in organization, content and vocabulary. On the other hand, the students getting the lowest score were 6. They did not understand well about descriptive text, especially several such as content, organization, vocabulary and grammar.

\section{Test Results in Control Class}

The data as result of the pre-test in control class can be read on table 4.3. Based on the table presented, it can be seen that the highest score in the pre test is 56.25 and the lowest score is 25.00. Meanwhile, the average score that the students got is 43.62. The students getting the highest score were 10 students. They understood about general descriptive material. It described with the score that they got in organization, content and vocabulary. On the other hand, the students getting the lowest score were 6 . They did not understand well about descriptive text, especially several such as content, organization, vocabulary and grammar.

In contrast, the rest of the students could understand well about aspects organization and vocabulary. But, they had some difficulties in creating their writing based on good content and grammar. Mostly, they were still confused with grammar used in descriptive text. 
Table 4

Pre-test and Post-test Score of Control Class

\section{Pre-test Score of Experimental Class Post-test Score of Experimental Class}

\begin{tabular}{|c|c|c|c|c|c|c|c|c|c|c|c|c|}
\hline Name & $\underset{\tilde{U}}{\stackrel{\overrightarrow{0}}{0}}$ & 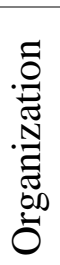 & 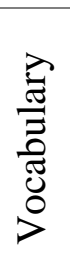 & 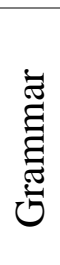 & $\stackrel{\overparen{\Xi}}{\stackrel{\pi}{0}}$ & $\begin{array}{l}\mathscr{J} \\
\tilde{U}\end{array}$ & 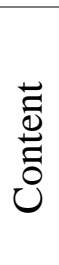 & 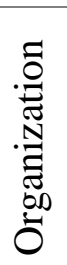 & 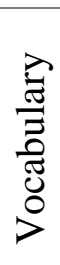 & 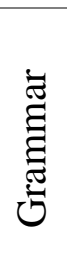 & $\underset{\stackrel{\pi}{0}}{\stackrel{\pi}{0}}$ & $\begin{array}{l}\stackrel{0}{0} \\
\stackrel{\mathscr{S}}{ }\end{array}$ \\
\hline S1 & 2 & 3 & 2 & 2 & 9 & 56.25 & 2 & 3 & 2 & 2 & 9 & 56.25 \\
\hline S2 & 2 & 2 & 3 & 2 & 9 & 56.25 & 2 & 2 & 3 & 2 & 9 & 56.25 \\
\hline S3 & 2 & 2 & 2 & 2 & 8 & 50.00 & 2 & 2 & 2 & 2 & 8 & 50.00 \\
\hline S4 & 2 & 3 & 2 & 2 & 9 & 56.25 & 2 & 3 & 2 & 2 & 9 & 56.25 \\
\hline S5 & 2 & 2 & 2 & 2 & 8 & 50.00 & 2 & 2 & 2 & 2 & 8 & 50.00 \\
\hline S6 & 3 & 2 & 2 & 2 & 9 & 56.25 & 3 & 2 & 2 & 2 & 9 & 56.25 \\
\hline S7 & 2 & 2 & 2 & 2 & 8 & 50.00 & 2 & 2 & 2 & 2 & 8 & 50.00 \\
\hline S8 & 2 & 2 & 2 & 2 & 8 & 50.00 & 2 & 2 & 2 & 2 & 8 & 50.00 \\
\hline S9 & 1 & 1 & 1 & 1 & 4 & 25.00 & 1 & 1 & 1 & 1 & 4 & 25.00 \\
\hline S10 & 1 & 1 & 1 & 1 & 4 & 25.00 & 1 & 1 & 2 & 1 & 5 & 31.25 \\
\hline S11 & 2 & 2 & 3 & 2 & 9 & 56.25 & 2 & 2 & 3 & 2 & 9 & 56.25 \\
\hline S12 & 2 & 2 & 2 & 2 & 8 & 50.00 & 2 & 2 & 2 & 2 & 8 & 50.00 \\
\hline S13 & 1 & 1 & 1 & 1 & 4 & 25.00 & 1 & 1 & 1 & 1 & 4 & 25.00 \\
\hline S14 & 2 & 2 & 2 & 2 & 8 & 50.00 & 2 & 2 & 2 & 2 & 8 & 50.00 \\
\hline S15 & 2 & 2 & 2 & 2 & 8 & 50.00 & 2 & 2 & 2 & 2 & 8 & 50.00 \\
\hline S16 & 1 & 1 & 1 & 1 & 4 & 25.00 & 1 & 1 & 1 & 2 & 5 & 31.25 \\
\hline S17 & 2 & 3 & 2 & 2 & 9 & 56.25 & 2 & 3 & 2 & 2 & 9 & 56.25 \\
\hline S18 & 1 & 1 & 1 & 1 & 4 & 25.00 & 1 & 1 & 1 & 1 & 4 & 25.00 \\
\hline S19 & 3 & 2 & 2 & 2 & 9 & 56.25 & 3 & 2 & 2 & 2 & 9 & 56.25 \\
\hline S20 & 1 & 1 & 1 & 1 & 4 & 25.00 & 1 & 1 & 1 & 2 & 5 & 31.25 \\
\hline S21 & 2 & 3 & 2 & 2 & 9 & 56.25 & 2 & 3 & 2 & 2 & 9 & 56.25 \\
\hline S22 & 2 & 2 & 2 & 2 & 8 & 50.00 & 2 & 2 & 2 & 2 & 8 & 50.00 \\
\hline S23 & 2 & 2 & 3 & 2 & 9 & 56.25 & 2 & 2 & 3 & 2 & 9 & 56.25 \\
\hline S24 & 2 & 2 & 3 & 2 & 9 & 56.25 & 2 & 2 & 3 & 2 & 9 & 56.75 \\
\hline S25 & 2 & 2 & 1 & 2 & 7 & 43.75 & 2 & 2 & 1 & 2 & 7 & 43.75 \\
\hline S26 & 2 & 2 & 2 & 2 & 8 & 50.00 & 2 & 2 & 2 & 2 & 8 & 50.00 \\
\hline S27 & 2 & 2 & 2 & 2 & 8 & 50.00 & 2 & 2 & 2 & 2 & 8 & 50.00 \\
\hline S28 & 1 & 1 & 1 & 2 & 5 & 31.25 & 1 & 1 & 1 & 1 & 4 & 25.00 \\
\hline S29 & 1 & 1 & 1 & 2 & 5 & 31.25 & 1 & 1 & 1 & 1 & 4 & 25.00 \\
\hline S30 & 2 & 2 & 2 & 2 & 8 & 50.00 & 2 & 2 & 2 & 2 & 8 & 50.00 \\
\hline
\end{tabular}

In calculating the normal distribution, the Kolmogorov-Smirnov with level of sig. $\alpha 0.05$ was used. It was conducted to check whether or not the pre-test of both group where normality distributed. 
The hypothesis of this test is :

Ho $=$ the score of experimental and control class are normality distributed

Table 5

Test of Normality

\begin{tabular}{lcccccrr}
\hline & \multicolumn{2}{c}{ Kolmogorov-Smirnov $^{\mathrm{a}}$} & \multicolumn{3}{c}{ Shapiro-Wilk } \\
\cline { 2 - 8 } & Statistic & df & \multicolumn{1}{c}{ Sig. } & Statistic & df & \multicolumn{1}{c}{ Sig. } \\
\hline PRETEST CONTROL & .108 & 30 & .200 & .975 & 30 & .680 \\
\hline PRETEST EXPERIMENT & .100 & 30 & .200 & .975 & 30 & .683 \\
\hline
\end{tabular}

Levene Statistic in SPSS 23 for windows to analyze the homogeneity of variance of experiment and control class pre-test score with level sig. $\alpha 0.05$ was used. The hypothesis of this test is :

Ho : the variance of the experimental and the control group are homogeneous.

The homogeneity of variance test result is presented in the following table :

Table 6

Test of Homogeneity of variance

\begin{tabular}{llll}
\hline Levene Statistic Control & df1 & df2 & Sig. \\
\hline 2.169 & 4 & 25 & .102 \\
\hline
\end{tabular}

The table above shows that the probability of the homogeneity of variance control test is 0.102 which is higher than the level of significance 0.05 , thus it can be concluded that null hypothesis is accepted and the variance of the two groups are equal.

T-Test was used to identify whether the means of experiment and control class were significantly different. The level sig. $\alpha 0.05$ was used in this test. Ho indicates that the two samples are from the same population, there are no significant differences between the two samples. The result of Paired Sample T-Test is presented as following table:

Table 7

Paired Samples Test

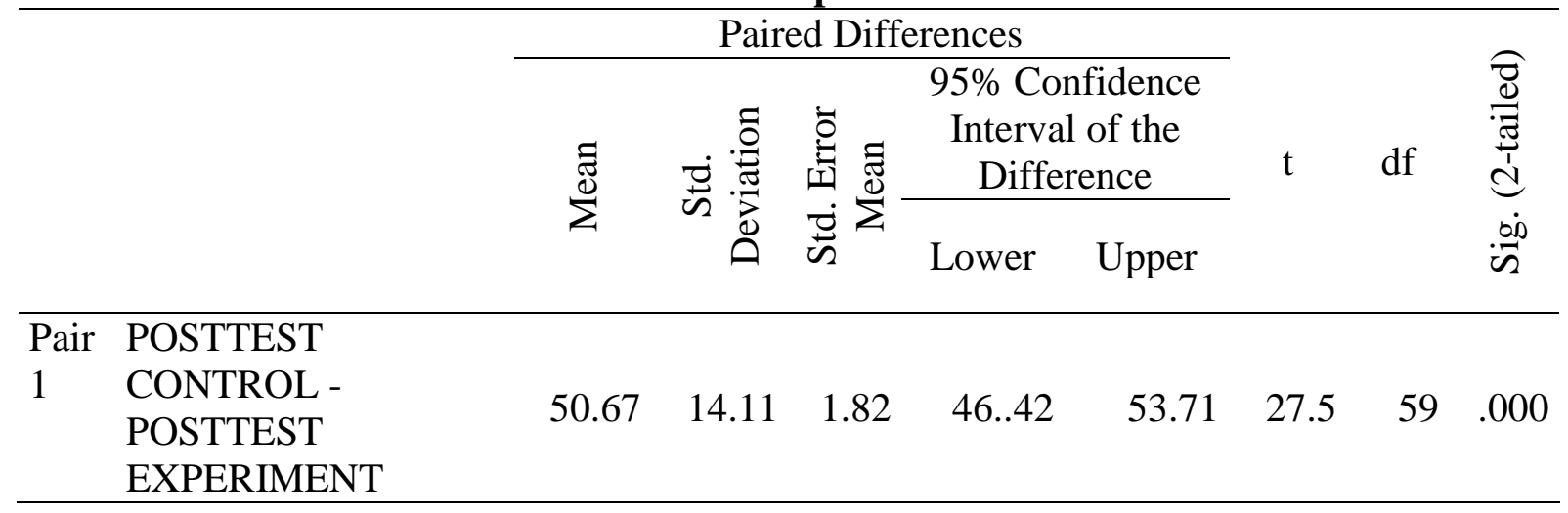

\section{Discussion}


The result proved that significance of the means by both groups for equal variances assumed is 0.000 and it was lower than 0.05 . Therefore the null hypothesis was rejected. It is indicated that there was a significant difference between the post-test means of experiment and control group had effected significantly in improving student's writing ability. It is in accordance with the statement coming from (Suzuki, 2005) stating that feedback can improve and help students to learn better. Besides, it helps students to learn more about what should be fixed from their work. Therefore, it helps them to get better understanding resulting better score.

The post-test score in both control and experiment class showed that the data distribution in both classes were normally distributed and the researcher use Paired Sample T-Test in order to analyze the significant effect of post-test score, the result showed that the experiment group had significantly different. The result of the calculation by using T-Test showed that Sig.(2-tailed) is 0.000 which was lower than 0.05 . Therefore the null hypothesis was rejected. It means that the treatments which were given to experiment group was significantly improve student's writing ability. In line with the statement from Lewis (2002), Muth'im \& Latief (2014), feedback provides students with language input. Regardless the form of feedback, written or spoken, it can be seen that both of them are beneficial and meaningful to enhance the students' language input. Since every student has his or her own mistakes, the input will be more specific and personal, thus addressing his or her needs. Therefore, it gives the students more opportunities to learn new vocabularies and structures in context.

The study also shows that feedback can lead students toward their autonomy in writing. It is also in line with (Haoucha, 2012) who states that students can get better writing skill when they are familiar with the way teacher treats them by giving them appropriate feedback. Here, in this study, minimal marking feedback could lead them into their independency in finding and detecting their mistakes resulting better writing. Also, one long-term purpose of feedback is to guide students in order they can find their own mistakes. So that, when students can analyze their mistakes, they will indirectly lead them in learning autonomy.

Besides, another thing found in the study, especially during the learning process, the students felt motivated to learn more. It is in line with Lewis (2002), Muth'im \& Latief (2014) who state that feedback is a form of motivation. The students were motivated because they needed to think about how to fix their work based on given feedback. Therefore, they were curious to find it leading them to learn more to get the information needed. Moreover, this condition indirectly encouraged the students to learn and to use language to improve their ability by taking into account every comment given by the teacher.

\section{CONCLUSION}

There are two major conclusions found. They are (1) there is significant improvement in students' writing skill, especially in writing descriptive text, for experimental groups after having minimal marking feedback as treatment; (2) there is no significant improvement in writing descriptive text for students who did not have minimal marking feedback as treatment (control group). The result can be seen based on the data calculated by SPSS Statistics version 23. The computation of pre-test score both in control and experiment classes that the data distribution in both of classes was normality distributed and homogeneity of the data was homogenous. Therefore, the statistical test hypothesis or comparing two means is Paired Sample T-Test. Based on the result and the data above, it can be concluded that the students who have been thought writing using minimal marking feedback had better writing than the 
students who did not learn writing using minimal marking feedback. This technique is effective for students' writing. This means that teaching writing descriptive text using minimal marking feedback is successful because their writing ability have significantly improved especially in writing descriptive text.

\section{ACKNOWLEDGMENTS}

We thank the family, parents, friends who have given us support both morally and so that we can complete and publish our article.

\section{REFERENCES}

Andie, T., Muijis, D., \& McAteer, E. (2011). Quantitative Methods In Educational And Social Research Using Spss. Berkshire: Mc Graw Hill Education.

Best, W. J. (1998). Research in Education. Michigan, USA: Allyn and Bacon, Inc.

Brown, D. H., \& Lee, H. (2015). Teaching by Principles: An Interactive Approach to Language Pedagogy (4th ed.). San Fransisco: Pearson Education.

Cameroon, L. (2001). Teaching Languages to Young Learners (1st ed.). Cambridge, U.K: Cambridge University Press.

Cresswell, W. J. (2017). Research Design Qualitative, Quantitative and Mixed Methods Approaches (CEC) (4th ed.). USA: SAGE Publications, Inc.

Ferris, D. (2011). Treatment of Error in Second Language Student Writing, Second Edition (2nd ed.). Michigan, USA: The University of Michigan Press.

Grabe, W., \& Kaplan, B. R. (2014). Theory and Practice of Writing: An Applied Linguistic Perspective (2nd ed.). New York, USA: Routledge London and New York.

Gronlund, E. N. (1990). Measurement and Evaluation in Teaching (6th ed.). New York:

Haoucha, M. (2012). the Role of Peer Feedback, Teacher Written and Taped. International Journal of Arts \& Sciences, 5(5), 73-108. Retrieved from https://une.idm.oclc.org/login?url=http://search.proquest.com?url=http://search.proquest. com/docview/1355855439? accountid=12756lnhttp://qa3nq3jm4u.search.serialssolutions. com/?ctx_ver=Z39.88-2004\&ctx_enc=info:ofi/enc:UTF-

8\&rfr_id=info:sid/ProQ:pqrl\&rft_va

Harmer, J. (2007). The Practice of English Language Teaching (4th ed.). U.K: Pearson Longman.

Harmer, J. (2012). How to Teach English. U.K: Pearson Longman.

Hyland, K. (2003). Second Language Writing. Cambridge, U.K: Cambridge Language Education.

Lewis, M. (2002). Giving feedback in language classes. SEAMEO Regional Language Centre, $v 5$,

Retrieved

from

https://scholar.google.co.id/scholar?hl=id\&as_sdt=0\%2C5\&q=Lewis\%2C+M.+\%28200 $2 \% 29 .+$ Giving+Feedback+in+Language+Classes.+SEAMEO+Regional+Language+Cen tre. $+\& b \operatorname{tnG}=$

Muth'im, A., \& Latief, M. A. (2014). The Effectiveness of Indirect Error Correction Feedback on the Quality of Students' Writing. Arab World English Journal, 5(2), 244-257.

Purnawarman, P. (2013). Impacts of Different Types of Teacher Corrective Feedback in Reducing Grammatical Errors on ESL/EFL Students' Writing. Journal of Chemical Information and Modeling, 53(9), 1689-1699. https://doi.org/10.1017/CBO9781107415324.004

Saville, M., \& Troike. (2006). Introducing Second Language Acquisition. New York: Cambridge University Press. 
Srichanyachon, N. (2012). Teacher written feedback for L2 learners' writing development. Silpakorn University Journal of Social Sciences, Humanities, and Arts, v12(1), 7-17. Retrieved from https://scholar.google.co.id/scholar?hl=id\&as_sdt=0\%2C5\&q=srichanyachon\&oq=sricha $\mathrm{n}$

Suzuki, M. (2005). Corrective feedback and learner uptake in adult ESL classrooms. ... College, Columbia University Working Papers in ..., 4(2), 1-21. https://doi.org/10.1017/S0958344004001120

Thompson, G. J. (2009). The First-Year Teacher's Survival Guide (2nd ed.). San Fransisco: Jossey-Bass. 